\title{
The Oral Glucose Tolerance Test: An Old but Irreplaceable Test to Evaluate Glucose Metabolism and Cardiovascular Risk
}

\author{
Gian Paolo Fra, Ettore Bartoli and Gian Piero Carnevale Schianca \\ Internal Medicine, Department of Internal and Experimental Medicine, East Piedmont \\ "Amedeo Avogadro" University \\ Italy
}

\section{Introduction}

The International Diabetes Federation estimates that near 285 million people have known type 2 diabetes: their number will probably double within 20 years (Shaw et al., 2010). Furthermore, worldwide, the number of persons with prediabetes, defined as impaired fasting glucose (IFG) or impaired glucose tolerance (IGT) (Genut et al., 2003), is estimated to be 314 million and is expected to be 418 million in 2025 (Garber et al., 2008). This scenario, amplified by the fact that several subjects do not know they have diabetes (Garber et al., 2008), has a predictable consequence: as the prevalence and progression to type 2 diabetes continues to increase and the afflicted population's age rises, the associated complications of diabetes inevitably will emerge as a major public health care issue. In 2007, for example, the direct and indirect costs related to diabetes, diabetes complications and general medical care amounted to \$ 174 billions in the United States (American Diabetes Association [ADA], 2008). Thus, the advantage not only to diagnose, but also to recognize as soon as possible subjects at high risk to develop type 2 diabetes, is evident. If, on one hand, the magnitude of morbidity and early mortality attributable to diabetes has been clearly shown (ADA, 2008), on the other hand a growing body of evidence indicates that earlier detection and consequent earlier treatment of hyperglycaemia and related metabolic abnormalities may be beneficial (DREAM Trial Investigators, 2006; Knowler et al., 2002). In fact, early detection and treatment of subjects with prediabetes has the potential of reducing or delaying the progression to diabetes (DREAM Trial Investigators, 2006; Gillies et al., 2007; Knowler et al., 2002) and related cardiovascular disease (Chiasson et al., 2003; Ratner et al., 2005).

The risk associated with progression to diabetes and cardiovascular complications increases along a continuum, rather than being threshold-dependent, and occurs at much lower glucose levels than those required to diagnose diabetes. Consequently, relying exclusively on diabetic glucose level may delay treatment (Bergman, 2010), as we need to maximize our efforts in diabetes prevention and early disease management.

How can we identify not only unknown diabetics but, above all, those subjects with glucose levels not yet in the diabetic range, who do instead mostly need preventive interventions? 
Although the increase in diabetes risk already starts at fasting plasma glucose (FPG) levels still within the normal range (Schulze et al., 2010; Tirosh et al., 2005), it follows that the FPG alone conveys inadequate information.

Recently the American Diabetes Association (ADA) proposed the measurement of glycosylated haemoglobin (A1c) to stratify glucose tolerance (International Expert Committee, 2009). Although A1c represents an easy screening test, and it is not influenced by fasting, drinking a glucose solution, or waiting hours for blood drawing, we believe that it cannot substitute for the information obtained derived from the oral glucose tolerance test (OGTT). In fact the contributions of FPG and post-prandial glucose to A1c levels are not linear: elevated FPG is mostly responsible for higher A1c levels. Instead, borderline A1c values, just above the upper limits of normal, strongly depend upon post-prandial glucose (Monnier et al., 2003). In support of these considerations, the results of well-designed studies (Fajans et al., 2011; Kramer et al., 2010) substantially indicate the insufficient sensitivity of A1c in detecting early diabetes.

Actually the OGTT, based on FPG and $2 \mathrm{~h}$ plasma glucose (2hPG) after ingestion of $75 \mathrm{~g}$ of glucose (Genut et al., 2003), is currently considered the gold standard to establish whether a subject has normal glucose tolerance (NGT) or altered glucose homeostasis.

In this report, we will discuss the OGTT. In our opinion, this old test, judged obsolete and inaccurate to the point of being considered optional according to ADA recommendations, should be instead reconsidered because of its irreplaceable clinical utility. Moreover, it could provide clear-cut metabolic information capable of recognizing subjects endowed with a metabolic profile prone to a progressive derangement in glucose homeostasis, suggestive of a high risk to develop diabetes.

\section{The history of the OGTT}

The OGTT is an old test used to diagnose alterations in glucose metabolism; its actual design is the result of a continuous reshaping that has lasted decades.

The notions that fasting hyperglycemia is too late a criterion for the early diagnosis of type 2 diabetes and that many subjects had obvious diabetes when their glucose was measured after a meal, led to the development, by the 1960s, of at least six different procedures for standardized OGTT. This debate involved the glucose load, ranging from 50 to $100 \mathrm{~g}$, several time-points and, especially, the choice of the diagnostic cut-off of glycemic values (Herman, 2007; Valleron et al., 1975).

Based upon the analysis on the bimodal plasma glucose distribution firstly observed in Pima Indians, in 1979 the National Diabetes Data Group (National Diabetes Data Group, 1979) and, subsequently, in 1997 the ADA (ADA, 1997), established the correct procedure and interpretation of OGTT. In particular:

1. The standard glucose load was set at $75 \mathrm{~g}$ p.o.

2. Two stages of glucose intolerance, intermediate between NGT and diabetes, were recognized from FPG and 2hPG: IGT was defined by a 2hPG of 140-199 mg/dl in 1979 and confirmed in 1997, and the IFG defined by a FPG of 110-125 mg/dl in 1997.

3. In 1997, the FPG cut-off value to diagnose diabetes was lowered from 140 to $126 \mathrm{mg} / \mathrm{dl}$. It was evident that the rationale for lowering the cut-off FPG levels $(126 \mathrm{mg} / \mathrm{dl}$ for diabetes and $110 \mathrm{mg} / \mathrm{dl}$ for IFG) was to make the OGTT, just developed and standardized, unnecessary. The ADA was predicting that FPG alone could stratify the different alterations of glucose metabolism, proceeding from NGT to diabetes with an intermediate glucose 
intolerance step constituted by IFG. The hope was that, by eliminating the OGTT, considered time consuming, poorly reproducible and not well accepted by patients, a larger number of subjects could be efficiently screened, diagnosed and treated using FPG alone. Unfortunately, FPG and 2hPG are not equivalent: the first measurement, becomes altered mainly by an impairment in the insulin-induced stimulation of hepatic glucose uptake, whereas postprandial glycemia (i.e.2hPG) rises because of delayed insulin secretion in combination with marked insulin resistance (Rizza, 2010). Thus, IFG and IGT are dependent upon different metabolic pathways. Our group did in fact supply evidence on the diversity of these pre-diabetic stages: we reported a relevant impairment of insulin secretion in IFG and an exquisite faltering in insulin sensitivity in IGT (Carnevale Schianca et al., 2003). Thus, it seems that prediabetes may represent a heterogeneous entity, which does not only entail an increased risk of diabetes, but also of cardiovascular disease (Garber et al., 2008). The attempt to screen glucose tolerance using FPG alone has been disavowed by several epidemiological observations. At variance with one single study involving three ethnic groups in the United Kingdom (Unwin et al., 1998), reporting a better prediction for diabetes from FPG with respect to 2hPG, FPG alone was shown to underestimate the diabetes prevalence when compared to 2hPG (Cheng et al., 2006; Harris et al., 1997). To ameliorate the diagnostic power of FPG, in 2003 the ADA lowered from 110 to $100 \mathrm{mg} / \mathrm{dl}$ its cut-off to define prediabetes (Genut et al., 2003). This did not meet the predicted expectations. As an example, a revealing study involving young African-American subjects compared FPG to OGTT to diagnose glucose intolerance. FPG $(110 \mathrm{mg} / \mathrm{dl})$ detected only $27.4 \%$ of cases, OGTT $87,1 \%$; when the 2003 ADA criteria were applied, the FPG threshold of $100 \mathrm{mg} / \mathrm{dl}$ did not perform any better, identifying only $28.9 \%$ of glucose intolerance cases (Cheng et al., 2006). Furthermore, beside the evidence that FPG cannot be equated to 2hPG (Carnevale Schianca et al., 2003; Rizza, 2010), it has been demonstrated that 2hPG more efficiently predicts the risk of heart disease than FPG (DECODE Study Group, 1998).

Moreover, although substituting FPG for 2PG seems attractive and convenient both on epidemiological and clinical grounds, it does not yield any metabolically relevant information. The point is that it is misleading to try to assess glucose homeostasis and, at the same time, to stratify cardiovascular risk, without informations derived from post-prandial glucose metabolism. To compare the relative importance of FPG vs 2hPG in detecting diabetes, we studied different FPG cut-off values in detecting glucose intolerance separately identified by OGTT (Sainaghi et al., 2007). Out of 202 subjects with FPG $\geq 100 \mathrm{mg} / \mathrm{dl}, 121$ (60\%) had $2 \mathrm{hPG}<140 \mathrm{mg} / \mathrm{dl}$; conversely, out of 452 subjects with FPG $<100 \mathrm{mg} / \mathrm{dl}, 61$ (14\%) had a $2 \mathrm{hPG} \geq 140 \mathrm{mg} / \mathrm{dl}$. Choosing arbitrarily a FPG cut-off of $90 \mathrm{mg} / \mathrm{dl}, 33$ out 266 subjects $(12 \%)$ still had abnormal $2 \mathrm{hPG}$. These data clearly demonstrate that any reduction of FPG threshold produces a progressive rise in sensitivity coupled to a progressive fall in specificity in detecting high-risk subjects for diabetes. Only the simultaneous information obtained from 2hPG (i.e. OGTT) allows the screening to become effective.

The next point will be explicative of the clinical utility of OGTT.

\section{The OGTT in "action"}

Despite various attempts to lower the cut-off of FPG to avoid the necessity of executing OGTT, there are extensive data showing that OGTT is more sensitive than FPG alone for diagnosing diabetes or prediabetes (Cheng et al., 2006; Harris et al., 1997; Meigs et al., 2003). 
To illustrate the considerable clinical information obtained from the routine execution of OGTT, we will show the results gathered in a cohort of asymptomatic subjects attending a metabolic patient facility.

A series of consecutive 1665 patients with unknown diabetes, underwent an OGTT because of the presence of risk factors such as obesity, hypertension, diabetes inheritability, or dyslipidaemia. In agreement with the 2003 ADA criteria (Genut et al., 2003), as shown in Fig. 1 section A, relying on FPG alone, 1023 subjects (61.4\%) were NGT (FPG <100 mg/dl) (group 1), while 642 were affected by glucose intolerance. Of these, 561 had IFG (group 2), 81 diabetes (group 3 ). As a consequence $4.9 \%$ of subjects (group 3) could start the necessary treatments, including pharmacotherapy, while $33.7 \%$ (group 2), classified as prediabetics, should be trained to follow appropriate lifestyle changes. Obviously, the remaining $61.4 \%$ (group 1), considered "normal", should perhaps be invited to follow scheduled FPG controls.

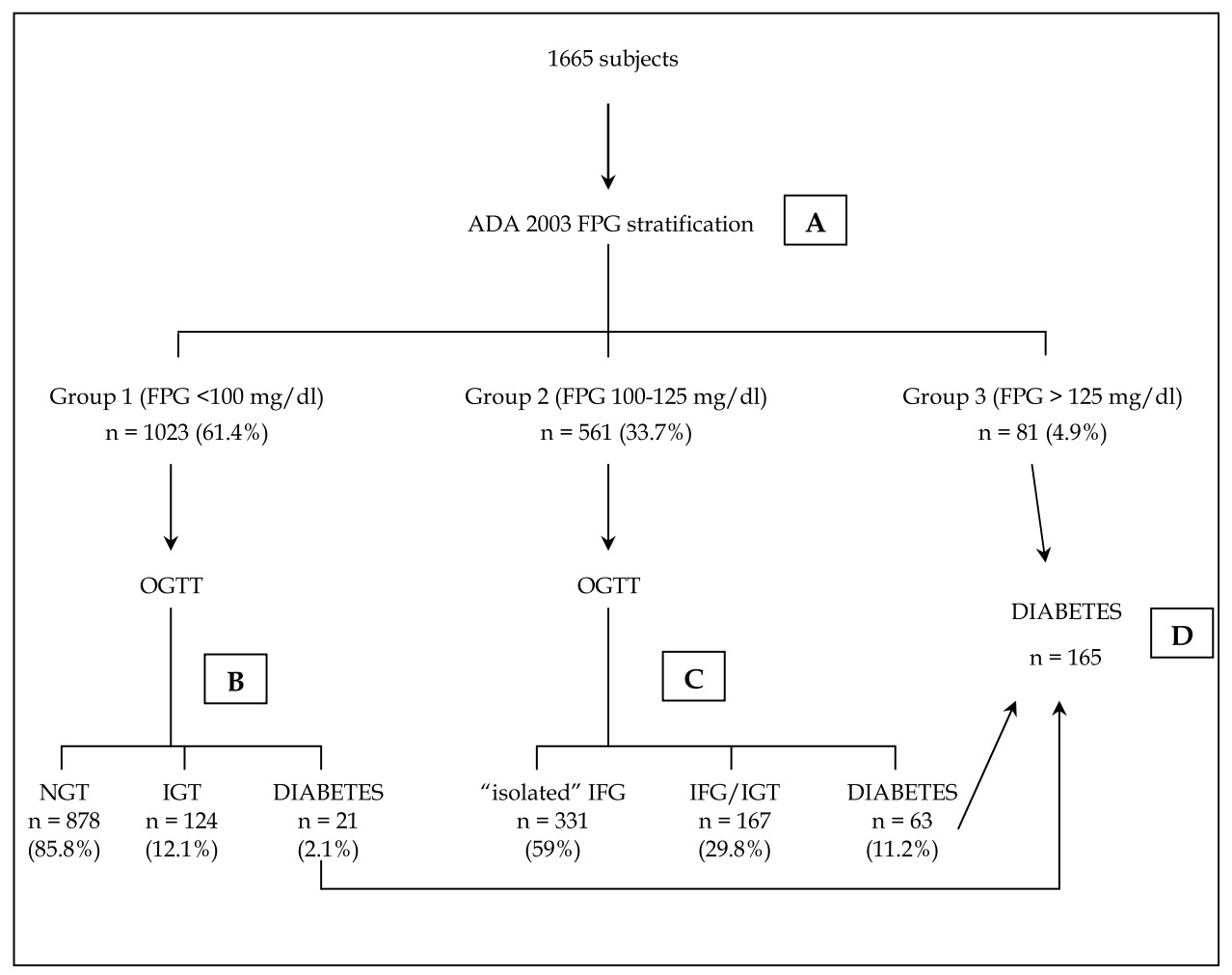

Fig. 1. The stratifications of FPG and OGTT in a cohort of 1665 subjects.

In section A it is shown the ADA 2003 FPG stratification; in section B the OGTT stratification in Group 1 and, in section C, in Group 2. In section D the contributions of both FPG and OGTT to detect subjects with diabetes are shown.

Probably this would be the scenario if FPG were the only test executed for diabetes screening. Using, in addition, criteria for the metabolic syndrome or A1c would not 
substantially increase the detection power of such a procedure (Expert Panel on detection, evaluation, and treatment of high blood cholesterol in adults, 2001 Fajans et al., 2011; Garber et al., 2008; Kramer et al., 2010).

Will the OGTT add importantly to the previous screening? If we consider group 1 (i.e. subjects with FPG $<100 \mathrm{mg} / \mathrm{dl}$ ), we note, as shown in Fig. 1 section B, that OGTT gives surprising results. A considerable proportion of these subjects $(14.2 \%)$ shows abnormal glucose tolerance, such that 124 subjects were affected by IGT and 21 by diabetes! From these data, we can formulate at least two considerations. Firstly, FPG, despite the decision to lower its threshold to more efficiently screen glucose abnormalities (Genut et al., 2003), continues to exhibit low specificity; secondly, OGTT is the only way to formally diagnose IGT, which constitutes the basic pathophysiologic alteration of type 2 diabetes. The identification of IGT is a crucial step in preventive cardiovascular strategies. The progression to diabetes is $6 \%$ to $10 \%$ per year for patients with IGT (Garber et al., 2008) and, similarly, a higher cardiovascular risk with elevated 2hPG has been reported even in the presence of normal FPG (DECODE Study Group, 1998). Thus, using FPG alone would deceitfully reassure a large proportion of individuals as being NGT and who will not be warned on the benefits of preventive treatments.

Let us now consider group 2, as shown in Fig. 1 (i.e. subjects with FPG 100-125 mg/dl). This large proportion of subjects should be labelled as affected by prediabetes and potentially susceptible of preventive therapies. In 2003, the ADA lowered FPG from 110 to $100 \mathrm{mg} / \mathrm{dl}$ to optimize sensitivity and specificity in detecting future diabetes (Genut et al., 2003). Nevertheless, this decision did not yield the expected results, as the development of diabetes in IFG varied widely (Davidson et al., 2003; Garber et al., 2008): for example, in our cohort of 1665 subjects, the percentage of IFG subjects ranged from $13.9 \%$ to $33.7 \%$, depending on whether we considered a FPG cut-off value of 110 (ADA, 1997), or of $100 \mathrm{mg} / \mathrm{dl}$ (Genut et al., 2003). The weakness of relying on FPG as the only mean to stratify glucose metabolism is then readily apparent. Moreover, the 561 IFG subjects (group 2) are far from being homogeneous as demonstrated by OGTT data of Fig. 1 section C: the majority of these subjects ( $n=331,59 \%)$ has normal 2hPG, such that they should be classified as "isolated" IFG, whereas $29.8 \%(\mathrm{n}=167)$ have $2 \mathrm{hPG} 140-199 \mathrm{mg} / \mathrm{dl}$, which indicates that are affected by combined IFG and IGT (IFG/IGT). Only 63 (11.2\%) had real type 2 diabetes.

It does not seem tenable to abandon OGTT in view of these data, which stress the usefulness of this test to correctly pinpoint, among subjects with similar IFG, those in need of a more accurate screening: they will be warned them about their risk of progression to diabetes, as well as their cardiovascular risk. Re-examining our OGTT data, these 63 subjects correctly identified as affected by diabetes would be promptly treated (DREAM Trail Investigators, 2006; Knowler et al., 2002), the 167 with IFG/IGT would be considered at high cardiovascular risk and, also, more liable to future diabetes (Garber et al., 2008): appropriate preventive strategies would be undertaken. Finally, the 331 subjects correctly identified as affected by "isolated" IFG by virtue of their $2 \mathrm{hPG}<140 \mathrm{mg} / \mathrm{dl}$, are probably at lower risk than those whose $2 \mathrm{hPG}$ was $\geq 140 \mathrm{mg} / \mathrm{dl}$ (Garber et al., 2008), suggesting only lifestyle changes and strict follow-up as initial preventive options. The crucial conclusion is that only OGTT permits this differentiation.

Fig. 1 section D shows the differential contributions of FPG versus OGTT in detecting subjects affected by diabetes: FPG individuated $49.1 \%$ of 165 subjects affected by diabetes, while OGTT allowed pinpointing an additional 50.9\%. In fact, $11.2 \%$ of 561 subjects with 
FPG $100-125$ and the $2.1 \%$ of the 1023 subjects with FPG $<100 \mathrm{mg} / \mathrm{dl}$ were truly affected by diabetes. This striking result emphasises the diagnostic weight of OGTT.

As a whole, the evidence of these data demonstrates that, without OGTT, the correct clinical management of a devastating metabolic disease becomes inefficient.

\section{The "expansion" of OGTT}

The worldwide pandemic of diabetes entails the early detection of high risk subjects to provide with appropriate treatment. Unfortunately, the diabetic risk starts already when FPG values are still within the normal range (Tirosh et al., 2005). It seems, however, unreasonable to classify the vast majority of the population as at risk, as these subjects are presently thought to progress along a continuum similar to that of other chronic diseases, like hypercholesterolemia and hypertension. Thus, using the "raw" OGTT alone, although of crucial clinical importance, may not be sufficient. Epidemiological observations reported that $\sim 40 \%$ of subjects who will develop diabetes exhibit NGT at baseline blood glucose testing, indicating that there is a large number of NGT subjects who constitute the largest reservoir of diabetes (Unwin et al., 2002). Moreover, the actual definition of prediabetes cannot provide an adequate solution of this dilemma, as not all subjects with IFG, IGT, or both, progress to diabetes; only 30 to $40 \%$ of IGT subjects do, in fact, ultimately convert to diabetes (Gerstein et al., 2007; Meigs et al., 2003). Thus, two questions arise: how to recognize normal subjects who will really develop diabetes in their future, and how to recognize prediabetic subjects who, in all likelihood, will never become diabetics.

The present "conventional" interpretation of OGTT, as well as methods using non-OGTT data (Expert Panel on detection, evaluation, and treatment of high blood cholesterol in adults, 2001; Kolberg et al., 2009; Stern et al., 2002), do not answer this question. Independent from the method used, all diabetes screening programmes do not reach the desired sensitivity and specificity. Consequently, a large number of subjects could inappropriately undergo prevention or, to the contrary, be excluded from beneficial interventions.

Recently, the relationship between FPG and 2hPG has been examined in a series of observations aimed at identifying NGT subjects at high risk for progression to diabetes (Abdul-Ghani et al., 2006; Abdul-Ghani et al., 2007; Abdul-Ghani et al., 2009). FPG and 2hPG closely correlate with $\beta$-cell function (Carnevale Schianca et al., 2003), the principal factor responsible for the development of diabetes (Gastaldelli et al., 2004). Changes in $\beta$ cell function also influence the shape of plasma glucose concentration profile during OGTT (Abdul-Ghani et al.; 2010 Tscritter et al., 2003). It has been reported that NGT subjects whose plasma glucose values fall faster to FPG levels during OGTT, have greater insulin sensitivity and better $\beta$-cell function compared to NGT subjects whose plasma glucose values fall more slowly (Abdul-Ghani et al., 2006; Abdul-Ghani et al., 2010; Carnevale Schianca et al., 2010). In agreement with the concept that the faster postload glucose drops towards FPG, or the lower postload glucose rises, the more efficient is $\beta$-cell function, we recently introduced a new dynamic appraisal of standard OGTT by computing the percentage increment of 2hPG with respect to FPG (PG\%), by using the formula [(2hPG - FPG) / FPG] x 100 (Bartoli et al., 2011; Carnevale Schianca et al., 2010; Carnevale Schianca et al., 2011). Since FPG and 2hPG, that are not interchangeable (Unwin et al., 1998), as they convey different information (Carnevale Schianca et al., 2003; 
Gastaldelli et al., 2004), PG\% could reflects the fine tuning between insulin secretion and sensitivity. We tested PG\% in relation to some estimated indexes of insulin sensitivity and insulin secretion derived from OGTT-data (Carnevale Schianca et al., 2010; Carnevale Schianca et al., 2011). Adding to glycemic measurements the simultaneous determinations of plasma insulin, Stumvoll et al. proposed, based on simple statistical methods using stepwise linear regression analysis and conceived for different sets of OGTT's time points, a series of formulas to calculate estimated indexes of insulin sensitivity and secretion (Stumvoll et al., 2001a). All these estimated indexes were validated by the clamp technique, the "gold" standard to evaluate the $\beta$-cell function (DeFronzo et al., 1979). Nevertheless, the evaluation of $\beta$-cell function using gold-standard method, is not practically feasible for epidemiological and clinical strategies (Stumvoll et al., 2001b). Among all indexes proposed by Stumvoll et al. we selected those that use FPG, 2hPG and the corresponding plasma insulin values. So with a single test, i.e. the OGTT with simultaneous determination of plasma insulin, it is possible to define not only the glucose tolerance and the PG\%, but also calculate insulin sensitivity and secretion. We reported that in each glucose tolerance group, the larger is PG\%, the lower is insulin sensitivity (Carnevale Schianca et al. 2011). Since insulin sensitivity is negatively related to insulin secretion through a hyperbolic function (Khan, 2003), glucose metabolism is thought to deteriorate when the fall in insulin sensitivity is not compensated by a sufficient increase of secretion. We demonstrated, for example, that NGT subjects with $2 \mathrm{hPG}$ near to or below FPG value (i.e., low PG\%), are more sensitive to insulin; they do not need, then, the enhanced insulin secretion that, on the contrary, is necessary for NGT subjects with high PG\%, a condition where there is a fall in insulin sensitivity (Carnevale Schianca et al., 2010). This is, in all likelihood, attended by an elevation of 2hPG, although still remaining within the "normal" range: probably the 2 hPG will remain "normal" until a compensatory insulin secretion is maintained. When this compensation fails, a derangement of glucose tolerance, probably heralded by a rise in PG\%, is unavoidable. The PG\% could therefore identify, within the NGT range, a distinct phenotype that may predispose to a worsening of glucose tolerance. As previously described in the San Antonio Metabolism study, subjects with $2 \mathrm{hPG}$ ranging from 121 to $139 \mathrm{mg} / \mathrm{dl}$ had a $60 \%$ reduction in $\beta$-cell function when compared to subjects with 2hPG $<120 \mathrm{mg} / \mathrm{dl}$ (Gastaldelli et al., 2004); this, and our data, demonstrate that $\beta$-cell function begins to deteriorate long before we can conventionally identify prediabetes.

The PG\% seems also useful when applied to subjects with glycaemic values within the IFG range. In 1997 the ADA proposed to diagnose IFG by FPG ranging from 110 to $125 \mathrm{mg} / \mathrm{dl}$ (American Diabetes Association, 1997) and, in 2003, widened this range by lowering the inferior limit of FPG to $100 \mathrm{mg} / \mathrm{dl}$, in the attempt to better predict the development of diabetes (Genut et al., 2003). However, this change increased the overall prevalence of IFG approximately three to fourfold, without any reliable advantage in diabetes prevention (Davidson et al., 2003; Garber et al., 2008; Unwin et al., 2002).

Fig.1 section A shows that the use of FPG alone allows to diagnose IFG in 561 out of 1665 subjects $(33.7 \%)$. Section $C$ shows the improved stratification of IFG subjects obtained by OGTT: $59 \%(n=331)$ of these, with $2 \mathrm{hPG}<140 \mathrm{mg} / \mathrm{dl}$, were really affected by "isolated" IFG. This is an example of the utility of standard OGTT to correctly differentiate subjects with similar FPG. Will all these 331 subjects with isolated IFG exhibit the same risk to progress to diabetes? Unfortunately, the standard OGTT, although useful in correctly stratify all subjects 
with FPG between 100 and $125 \mathrm{mg} / \mathrm{dl}$, does not help us any further. Instead, the calculation of PG\% could offer a possibility to recognize, even in the "isolated" IFG range, subjects with abnormalities in $\beta$-cell function predisposing to worsening glucose homeostasis.

As an example, we will consider the case of a subject whose OGTT yielded FPG $=107$ and $2 \mathrm{hPG}=110 \mathrm{mg} / \mathrm{dl}$, and then compare him with another subject whose OGTT gave FPG = 104 and $2 \mathrm{hPG}=136 \mathrm{mg} / \mathrm{dl}$. Both subjects suffer, by definition, from isolated IFG. Are they truly similar?

Recently, we demonstrated that the simple calculation of PG\% can differentiate subjects with isolated IFG into two different phenotypes, as the higher the PG\% the more dysfunctional is the $\beta$-cell (Carnevale Schianca et al., 2011). Likewise, even in the NGT and IFG/IGT ranges, we noted a progressive and meaningful worsening of insulin sensitivity proceeding from lower to higher PG\% values, while there were no changes in insulin secretion. Only within the NGT range was insulin secretion significantly higher in the upper PG\% values. We speculated that this increment, probably secondary to the derangement in insulin sensitivity, is the prerequisite to maintain a subject within the NGT range (Carnevale Schianca et al., 2010).

With this simple calculation of PG\%, we add to our diagnostic tools the possibility to detect the pathophysiologic difference between the two IFG subjects of the above example: the first patient has $\mathrm{PG} \%=2.8 \%$, the second one $=30.8 \%$. Probably, this latter subject has an important deterioration of $\beta$-cell function, very likely attended, in the future, by metabolic consequences which could be amenable to preventive treatments. The actual definition of the IFG range forces us to define as prediabetes a large section of the population; the application of PG\% can better define the real metabolic risk. As an example, considering the 331 subjects with "isolated" IFG shown in Fig. 1 section C, $156(47.1 \%)$ had a PG\% $\leq 0 \%$ : their 2hPG values suggest a metabolic efficiency hardly suggestive of a risk of future diabetes.

Unlike IFG, the recognition of IGT is exclusively based on OGTT, which can yield additional critical information if implemented by the computation of PG\%. We reported that, within the IGT range, a major increment of PG\% indicates subjects probably more liable to develop diabetes (Carnevale Schianca et al., 2010). Although no significant differences in insulin sensitivity and secretion could be disclosed considering a large spectrum of PG\%, when the insulin secretion was corrected by insulin sensitivity to estimate $\beta$-cell function (Utzschneider et al., 2009), it was significantly impaired in IGT subjects with higher PG\%. Since not all IGT subjects progress to diabetes (Gerstein et al., 2007; Meigs et al., 2003), and the decline in $\beta$-cell function favours this evolution (Festa et al., 2006), PG\% can identify, when elevated, a high-risk subgroup to which a more aggressive preventive treatment could be applied.

\section{Conclusions}

In conclusion, the PG\% can expand the clinical weight of OGTT by simply implementing a more powerful and informative calculation that discloses the efficiency of $\beta$-cell function. When high, probably the PG\% pinpoints a higher risk of worsening glucose homeostasis. Although prospective studies designed to test the utility of PG\% are needed, this computation has the advantage of being simple, feasible and of being obtained by the standard OGTT. This old test, conceived to investigate glucose tolerance and perhaps hurriedly considered obsolete and unsuitable, seems, on the contrary, irreplaceable. 


\section{References}

Abdul-Ghani, M.A.; Williams, K.; DeFronzo, R. \& Stern, M. (2006). Risk of progression to type 2 diabetes based on relationship between postload plasma glucose and fasting plasma glucose. Diabetes Care, Vol.29, NO.7, (July 2006), pp. 1613-1618, ISSN: 01495992

Abdul-Ghani, M.A.; Williams, K.; DeFronzo, R. \& Stern, M. (2007). What is the best predictor of future type 2 diabetes? Diabetes Care, Vol.30, No.6, (July 2007), pp. 1544-1548, Epub 2007 Mar 23, ISSN: 0149-5992

Abdul-Ghani, M.A.; Lyssenko, V.; Tuomi, T.; DeFronzo R. \& Groop, L. (2009). Fasting versus postload plasma glucose concentration and the risk for future type 2 diabetes: results from the Botnia study. Diabetes Care, Vol.32, No.2, (February 2009), pp. 281286, Epub 2008 Nov 18, ISSN: 0149-5992

Abdul-Ghani, M.A.; Lyssenko, V.; Tuomi, T.; DeFronzo, R.A. \& Groop, L. (2010). The shape of plasma glucose concentration curve during OGTT predicts future risk of type 2 diabetes. Diabetes/Metabolism Research and Reviews, Vol.26, No.4, (May 2010), pp. 280-286, ISSN: 1520-7552

American Diabetes Association. (1997). Report of the Expert Committee on the diagnosis and Classification of Diabetes Mellitus. Diabetes Care, Vol. 20, No.7, (July 1997), pp. 1183-1197, ISSN: 0149-5992

American Diabetes Association. (2008). Economics costs of diabetes in the U.S. in 2007. Diabetes Care, Vol.31, No.3, (March 2008), pp. 596-615, ISSN: 0149-5992

Bartoli, E.; Fra, G.P. \& Carnevale Schianca, G.P. (2011). The oral glucose tolerance test (OGTT) revisited. European Journal of Internal Medicine, Vol.22, No.1, (February 2011), pp. 8-12, Epub 2010 Aug 17, ISSN: 0953-6205

Bergman, M. (2010). Inadequacies of absolute threshold levels for diagnosing prediabetes. Diabetes/Metabolism Research and Reviews, Vol.26, No.1, (January 2010), pp. 3-6, ISSN: 1520-7552

Carnevale Schianca, G.P.; Rossi, A.; Sainaghi, P.P.; Maduli, E. \& Bartoli, E. (2003) The significance of impaired fasting glucose versus impaired glucose tolerance. Importance of insulin secretion and resistance. Diabetes Care, Vol.26, No.5, (May 2003), pp. 1333-1337, ISSN: 0149-5992

Carnevale Schianca, G.P.; Colli, E.; Onolfo, S.; Pedrazzoli, R.; Fra, G.P. \& Bartoli, E. (2010). Individuation of different metabolic phenotypes in normal glucose tolerance test. Acta Diabetol Acta Diabetologica, Vol.47, No.2, (June 2010) pp. 167-172, Epub 2009 Nov 21, ISSN: 0940- 5429

Carnevale Schianca, G.P., Mella, R.; Bigliocca, M.; Colli, E.; Fra, G.P. \& Bartoli, E. (2011). Expanding the clinical use of standard OGTT: the percentage increment of $2 \mathrm{~h}$ with respect to fasting glucose as an index of $\beta$-cell dysfunction. Diabetes/Metabolism Research and Reviews, Vol.27, No.3, (March 2011), pp. 262-268, doi: 10.1002/dmrr.1166, ISSN: 1520-7552

Cheng, C.; Kushner, H., \& Falkner, B.E. (2006). The utility of fasting glucose for detection of prediabetes. Metabolism Clinical and Experimental, Vol.55, No.4, (April 2006), pp. 434438, ISSN: 0026-0495

Chiasson, J.L. ; Josse, R.G. ; Gomis, R.; Hanefeld, M. ; Karasik, A. \& Laakso, M.; STOPNIDDM Trial Research Group. (2003). Acarbose treatment and the risk of cardiovascular disease and hypertension in patients with impaired glucose 
tolerance: The STOP-NIDDM trial. Journal of the American Medical Association, Vol.290, No.4, (July 2003), pp. 486-494, ISSN: 0098-7484

Davidson, M.B.; Landsman, P.B. \& Alexander, C.M. (2003). Lowering the criterion for impaired fasting glucose will not provide clinical benefit. Diabetes Care, Vol.26, No.12, (December 2003), pp. 3329-3332, ISSN: 0149-5992

DECODE Study Group, on behalf of the European Diabetes Epidemiology Study Group. (1998). Will new diagnostic criteria for diabetes mellitus change phenotype of patients with diabetes? Reanalysis of European epidemiological data. British Medical Journal, Vol.317, No.7155, (August 1998), 371-375, ISSN 0959-8138

DeFronzo, R.A.; Tobin, J.D. \& Andres, R. (1979). Glucose clamp technique: a method for quantifying insulin secretion and resistance. American Journal of Physiology: Endocrinology and Metabolism, Vol.237, No.3, (September 1979), E214-E223, ISSN 0193-1849

DREAM (Diabetes REduction Assessment with ramipril and rosiglitazone Medication) Trial Investigators, Gerstein, H.C.; Yusuf, S.; Bosch, J.; Poque, J.; Sheridan, P.; Dinccag, N.; Hanefeld, M.; Hoogwerf, B.; Laasko, M.; Mohan, V.; Shaw, J.; Zinman, B. \& Holman, R.R. (2006). Effect of rosiglitazone on the frequency of diabetes in patients with impaired glucose tolerance or impaired fasting glucose: a randomised controlled trial. Lancet, Vol.368, No.9541, (September 2006), pp. 1096-1105, ISSN 0140-6736

Expert Panel on Detection, Evaluation, and Treatment of High Blood Cholesterol in Adults. (2001). Executive summary of the third report of the National Cholesterol Education Program (NCEP) on detection, evaluation, and treatment of high blood cholesterol in adults (Adult Treatment Panel III). Journal of the American Medical Association, Vol.290, No.19, (May 2001), pp. 2486-2497, ISSN: 0098-7484

Fajans, S.S.; Herman, W.H. \& Oral, E.A. (2011). Insufficient sensitivity of hemoglobin (1C) determination in diagnosis or screening of early diabetic states. Metabolism Clinical and Experimental, Vol.60, No.1, (January 2011), pp. 86-91, Epub 2010 August 17, ISSN: 0026-0425

Festa, A.; Williams, K.; D’Agostino, R.; Wagenknecht, L.E. \& Haffner, S.M. (2006). The natural course of $\beta$-cell function in non-diabetic individuals. The insulin resistance atherosclerotic study. Diabetes, Vol.55, No.4, (April 2006), pp. 114-120, ISSN: 00121797

Garber, A.J.; Handelsman, Y.; Einhorn, D.; Bergman, D.A.; Bloomgarden, Z.T.; Fonseca, V.; Garvey, T.; Gavin, J.R.3rd; Grunberger, G.; Horton, E.S.; Jellinger, P.S.; Jones, K.L.; Lebovitz, H.; Levy, P.; McGuire, D.K.; Moghissi, E.S. \& Nesto, R.W. (2008). Diagnosis and management of prediabetes in the continuum of hyperglycemia: when the risk of diabetes begin? A consensus statement from the American College of Endocrinology and the American Association of Clinical Endocrinologists. Endocrine Practice, Vol.14, No.7, (October 2008), pp. 933-946, ISSN: 1530-891X

Gastadelli, A.; Ferrannini, E.; Miyazaki, Y.; Matsuda, M. \& DeFronzo, R.A.; San Antonio metabolism study. (2004). Beta-cell dysfunction and glucose intolerance: results from the San Antonio Metabolism (SAM) study. Diabetologia, Vol.47, No.1, (January 2004), pp. 31-39, Epub 2003 Dec 10, ISSN: 0012-186X

Genut, S.; Alberti, K.G.; Bennett, P.; Buse J.; DeFronzo, R.; Kahn, R.; Kitzmiller, J.; Knowler, W.C.; Lebovitz; H.; Lenmark, A.; Nathan, D.; Palmer, J.; Rizza, R.; Saudek, C.; Shaw, J.; Steffes, M.; Tuomilehto, J. \& Zimmet, P.; Expert Committee on the Diagnosis and Classification of Diabetes Mellitus (2003). Follow-up report on the 
diagnosis of diabetes mellitus. Diabetes Care, Vol.26, No.11, (November 2003), pp. 3160-3167, ISSN: 0149-5992

Gerstein, H.C.; Santaguida, P.; Raina, P.; Morrison, K.M.; Ballion, C.; Hunt, D.; Yazdi, H. \& Booker, L. (2007). Annual incidence and relative risk of diabetes in people with various categories of dyslglycemia: a systematic overview and meta-analysis of prospective studies. Diabetes Research and Clinical Practice, Vol.78, No.3, (December 2007), pp. 305-312, Epub 2007 Jun 29, ISSN: 0168-8227

Gillies, C.L.; Abrams, K.R.; Lambert, P.C.; Cooper, N.J., Sutton, A.J., Hsu, R.T. \& Khunti, K. (2007). Pharmacological and lifestyle interventions to prevent or delay type 2 diabetes in people with impaired glucose tolerance: systematic review and metaanalysis. British Medical Journal, Vol.334, No.7588, (February 2007), pp. 229, Epub 2007 Jan 19, ISSN: 0959-8138

Harris, M.I.; Eastman, R.C.; Cowie, C.C.; Flegal, K.M. \& Eberhardt, M.S. (1997). Comparison of diabetes diagnosis categories in the US population according to 1997 American diabetes Association and 1980-1985 World Health Organization diagnostic criteria. Diabetes Care, Vol.20, No.12, (December 1997), pp. 1859-1862, ISSN: 0149-5992

Herman, W.H. (2007). Diabetes epidemiology: guiding clinical and public health practice. The Kelly West Award Lecture, 2006. Diabetes Care, Vol.30, No. 7, (July 2007), pp. 1912-1919, Epub 2007 May 11, ISSN: 0149-5992

International Expert Committee. (2009). International Expert Committee Report on the role of the A1C assay in the diagnosis of diabetes. Diabetes Care, Vol.32, No.7, (July 2009), pp. 1327-1334, Epub 2009 Jun 5, ISSN: 0149-5992

Kahn, S.E. (2003). The relative contributions of insulin resistance and beta-cell dysfunction to the pathophysiology of type 2 diabetes. Diabetologia, Vol.46, No.1, (January 2003), pp. 3-19, Epub 2003 Jan 11, ISSN: 0012-186X

Knowler, W.C.; Barret-Connor, E.; Fowler, S.E.; Hamman, R.F.; Lachin, J.M.; Walker, E.A. \& Nathan, D.M. Diabetes Prevention Program Research Group. (2002). Reduction in the incidence of type 2 diabetes with lifestyle intervention or metformin. $N$ Engl J Med, Vol.346, No.6, (February 2002), pp. 393-403, ISSN: 0028-4793

Kolberg, J.A.; Jørgensen, T.; Gerwiev, R.W.; Hamren, S.; McKenna, M.P.; Moler, E.; Rowe, MW; Urdea, M.S.; Xu, X.M.; Hansen, T.; Pedersen, O. \& Borch-Johnsen, K. (2009). Development of a type 2 diabetes risk model from a panel of serum biomarkers from the Inter99 cohort. Diabetes Care, Vol.32, No.7, (July 2009), pp. 1207-1212, ISSN: 0149-5992

Kramer C.K., Araneta M.R.G., \& Barret-Connor, E. (2010). A1C and diabetes diagnosis: The Rancho Bernardo Study. Diabetes Care, Vol.33, No.1, (January 2010), pp. 101-103, Epub 2009 Oct 16, ISSN: 0149-5992

Meigs, J.B.; Muller, D.C.; Nathan, D.M.; Blake, D.R. \& Andres, R. (2003). The natural history of progression from normal glucose tolerance to type 2 diabetes in the Baltimore Longitudinal Study of Aging. Diabetes, Vol.52, No.6, (June 2003), pp. 1475-1484, ISSN: 0012-1797

Monnier, I.; Lapinski, H. \& Colette, C. (2003). Contributions of fasting and postprandial plasma glucose increments to the overall diurnal hyperglycemia of type 2 diabetic patients: variations with increasing levels of $\mathrm{HbA}(1 \mathrm{c})$. Diabetes Care, Vol.26, No.3, (March 2003), pp. 881-885, ISSN: 0149-5992

National Diabetes Data Group. (1979). Classification and diagnosis of diabetes mellitus and other categories of glucose intolerance. Diabetes, Vol.28, No.12, (December 1979), pp. 1039-1052, ISSN: 0012-1797 
Ratner, R.; Goldberg, R.; Haffner, S.; Marcovina, S.; Orchard, T.; Fowler, S. \& Temprosa, M. Diabetes Prevention Program Research Group. (2005). Impact of intensive lifestyle and metformin therapy on cardiovascular disease risk factors in the diabetes prevention program. Diabetes Care, Vol.28, No.4, (April 2005), pp. 888-94, ISSN: 0149-5992

Rizza, R.A. Pathogenesis of fasting and postprandial hyperglycemia in type 2 diabetes: implications for therapy. (2010). Diabetes, Vol.59, No.11, (November 2010), pp. 26972707, Epub 2010 Aug 12, ISSN: 0012-1797 59

Sainaghi, P.P.; Castello, L.; Limoncini, A.M.; Bergamasco, L.; Bartoli, E. \& Schianca, G.P.C. (2007). Poor specificity of fasting plasma glucose cut-off values in ruling out glucose intolerance: the complementary usefulness of OGTT. Experimental and Clinical Endocrinology \& Diabetes, Vol.115, No.2, (February 2007) pp. 112-7, ISSN 0947-7349

Schulze, M.B.; Fritsche, A.; Boeing, H. \& Joost, H.G. Fasting plasma glucose and type 2 diabetes risk: a non-linear relationship. (2010) Diabetic Medicine, Vol.27, No.4, (April 2010), pp. 473-476, ISSN: 0742-3071

Shaw, J.E.; Sicree, R.A. \& Zimmet, P.Z. Global estimates of the prevalence of diabetes for 2010 and 2030. (2010) Diabetes Research and Clinical Practice, Vol.87, No.1, (January 2010), pp. 4-14, Epub 2009 Nov 6, ISSN: 0168-8227

Stern, M.P.; Williams, K. \& Haffner, S.M. Identification of persons at high for type 2 diabetes mellitus: do we need the oral glucose tolerance test? (2002). Ann Intern Med Annals of Internal Medicine, Vol.136, No.8, (April 2002), pp. 575-81, ISSN: 0003-4819

Stumvoll, M.; Van Haeften, T.; Fritsche, A. \& Gerich, J. Oral glucose tolerance test indexes for insulin sensitivity and secretion based on various availabilities of sampling times. (2001a) Diabetes Care, Vol.24, No4, (April 2001), pp. 796-797, ISSN: 0149-5992

Stumvoll, M.; Fritsche, A. \& Häring, H. The OGTT as test for beta cell function? (2001b) European Journal of Clinical Investigation, Vol.31, No.5 (May 2001), pp. 380-381, ISSN: 0014-2972

Tirosh, A.; Shai, I.; Tekes-Manova, D.; Israeli, E.; Pereg, D.; Shochat, T.; Kochba, I., \& Rudich, A.; Israeli Diabetes Research Group. (2005). Normal fasting plasma glucose levels and type 2 diabetes in young men. N Engl J Med, Vol.353, No.14, (October 2005), pp. 1454-1462, ISSN: 0028-4793

Tschritter, O.; Fritsche, A.; Shirkavand, F.; Machicao, F.; Haring, H. \& Stumvoll, M. (2003). Assessing the shape of the glucose curve during an oral glucose tolerance test. Diabetes Care, Vol.26, No.4, (April 2003), pp. 1026-1033, ISSN: 0149-5992

Unwin, N.; Alberti, K.G.; Bhopal, R.; Harland, J.; Watson, W., \& White, M. (1998). Comparison of the current WHO and new criteria for the diagnosis of diabetes mellitus in three ethnic groups in the UK. Diabetic Medicine, Vol.15, No.7, (July) pp. 554-557, ISSN: 0742-3071

Unwin, N.; Shaw, J.; Zimmet, P. \& Alberti, K.G. (2002). Impaired glucose tolerance and impaired fasting glycaemia: the current status on definition and intervention. Diabetic Medicine, Vol.19, No.9, (September 2002), pp. 708-723, ISSN: 0742-3071

Utzschneider, K.M.; Prigeon, R.L.; Faulenbach, M.V.; Tong, J.; Carr, D.B.; Boyko, E.J.; Leonetti, D.L.; McNeely, M.J.; Fujimoto, W.Y. \& Kahn, S.E. (2009). Oral disposition index predicts the development of future diabetes above and beyond fasting and 2h glucose levels. Diabetes Care, Vol.32, No.2, (February 2009), pp. 335-341, Epub 2008 Oct 28, ISSN: 0149-5992

Valleron, A.J.; Eschwège, E.; Papoz, L., \& Rosselin, G.E. (1975). Agreement and discrepancy in the evaluation of normal and diabetic oral glucose tolerance test. Diabetes, Vol.24, No.6, (June 1975), pp. 585-593, ISSN: 0012-1797 


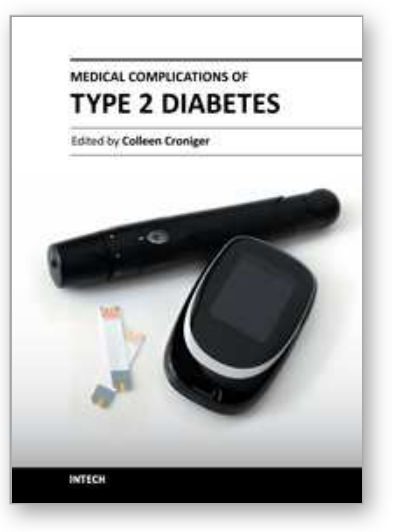

\author{
Medical Complications of Type 2 Diabetes \\ Edited by Dr. Colleen Croniger
}

ISBN 978-953-307-363-7

Hard cover, 412 pages

Publisher InTech

Published online 12, September, 2011

Published in print edition September, 2011

Obesity and type 2 diabetes are increasing worldwide problems. In this book we reviewed insulin secretion in both healthy individuals and in patients with type 2 diabetes. Because of the risk associated with progression from insulin resistance to diabetes and cardiovascular complications increases along a continuum, we included several chapters on the damage of endothelial cells in type 2 diabetes and genetic influences on endothelial cell dysfunction. Cardiovascular complications occur at a much lower glucose levels, thus a review on the oral glucose tolerance test compared to other methods was included. The medical conditions associated with type 2 diabetes such as pancreatic cancer, sarcopenia and sleep disordered breathing with diabetes were also discussed. The book concludes with several chapters on the treatments for this disease offering us hope in prevention and successful alleviation of the co-morbidities associated with obesity and type 2 diabetes.

\title{
How to reference
}

In order to correctly reference this scholarly work, feel free to copy and paste the following:

Gian Paolo Fra, Ettore Bartoli and Gian Piero Carnevale Schianca (2011). The Oral Glucose Tolerance Test: An Old but Irreplaceable Test to Evaluate Glucose Metabolism and Cardiovascular Risk, Medical Complications of Type 2 Diabetes, Dr. Colleen Croniger (Ed.), ISBN: 978-953-307-363-7, InTech, Available from: http://www.intechopen.com/books/medical-complications-of-type-2-diabetes/the-oral-glucose-tolerancetest-an-old-but-irreplaceable-test-to-evaluate-glucose-metabolism-and-car

\section{INTECH}

open science | open minds

\section{InTech Europe}

University Campus STeP Ri

Slavka Krautzeka 83/A

51000 Rijeka, Croatia

Phone: +385 (51) 770447

Fax: +385 (51) 686166

www.intechopen.com

\section{InTech China}

Unit 405, Office Block, Hotel Equatorial Shanghai

No.65, Yan An Road (West), Shanghai, 200040, China 中国上海市延安西路65号上海国际贵都大饭店办公楼 405 单元

Phone: +86-21-62489820

Fax: +86-21-62489821 
(C) 2011 The Author(s). Licensee IntechOpen. This chapter is distributed under the terms of the Creative Commons Attribution-NonCommercialShareAlike-3.0 License, which permits use, distribution and reproduction for non-commercial purposes, provided the original is properly cited and derivative works building on this content are distributed under the same license. 